\title{
Human Intrahepatic Biliary Epithelial Cells Proliferate In Vitro in Response to Human Hepatocyte Growth Factor
}

\author{
Ruth Joplin, * Tadashi Hishida, ${ }^{*}$ Hirohito Tsubouchi, " Yasushi Daikuhara," Reuben Ayres, * \\ James M. Neuberger, * and Alastair J. Strain* \\ ${ }^{*}$ Liver Unit, Queen Elizabeth Hospital, Birmingham B15 2TH, United Kingdom; ${ }^{\ddagger}$ Mitsubishi Corp., Yokohama 227, Japan; ${ }^{\S}$ Second \\ Department of Internal Medicine, Kagoshima University Medical School and "Department of Biochemistry, Kagoshima University \\ Dental School, Kagoshima 890, Japan
}

\section{Abstract}

In previous studies, intrahepatic human biliary epithelial cells (BEC) were isolated in high purity. However, these cells demonstrated only limited growth responses. Here we report that human BEC proliferate in response to human hepatocyte growth factor (hHGF), retain BEC-specific phenotype, and can be serially passaged.

BEC showed dose-dependent growth in response to 0.01$100 \mathrm{ng} / \mathrm{ml}$ hHGF. The maximum S-phase labeling index reached $40 \%$ with half-maximal stimulation at $1 \mathrm{ng} / \mathrm{ml}$. The response of cells from normal and primary biliary cirrhotic liver to hHGF was similar. Cultures were immunostained with specific antibodies and then processed for $\left[{ }^{3} \mathrm{H}\right]$ thymidine autoradiography. Proliferating cells expressed BEC-specific markers (HEA125 and CK-19), but were negative for desmin and factor VIII-related antigen. Occasional vimentin-positive cells were observed, but these were nonproliferative. In conclusion, cells responding to hHGF were clearly BEC in origin.

The observation that HGF is mitogenic for BEC as well as hepatocytes has important implications. First, greater yields of intrahepatic BEC are available for subsequent studies of the pathogenesis and etiology of diseases of the biliary epithelium. Secondly, some means of regulating the cellular response to HGF in vivo must operate, in that HGF levels rise early after partial hepatectomy and yet BEC proliferate $24 \mathrm{~h}$ later than hepatocytes. (J. Clin. Invest. 1992.90:1284-1289.) Key words: biliary epithelial cell culture $\bullet$ human liver disease $\bullet$ liver regeneration • primary biliary cirrhosis $\bullet$ scatter factor

\section{Introduction}

To overcome the complexities of whole-animal experimentation, in recent years the regulation of mammalian liver regeneration has been investigated by means of in vitro approaches ( 1 , 2 ). Studies have focused upon the agents (nutrients, hor-

A preliminary report of this work was presented at the 42nd Meeting of the American Association for the Study of Liver Diseases, 25 November 1991, Chicago, IL and published in abstract form (1991. Hepatology. 14 [No. 4, Part 2]:103A).

Address reprint requests to Dr. Strain, Liver Research Laboratories, Queen Elizabeth Hospital, Edgbaston, Birmingham B15 2TH, United Kingdom.

Received for publication 4 December 1991 and in revised form 17 March 1992.

J. Clin. Invest.

(c) The American Society for Clinical Investigation, Inc. $0021-9738 / 92 / 10 / 1284 / 06 \$ 2.00$

Volume 90, October 1992, 1284-1289 mones, and growth factors) that initiate or potentiate DNA synthesis and cell division in isolated hepatocytes, inasmuch as this cell population is the first to respond mitogenically to the growth signals in vivo (3). In the rat, hepatocytes traverse from growth quiescence to S-phase with a first peak of DNA synthesis after 16-18 h, mitosis following some $6 \mathrm{~h}$ later (4). The other cell types of the liver, including biliary epithelial cells (BEC), ${ }^{1}$ endothelial cells, and lipocytes, are said to proliferate with a lag of a further $24 \mathrm{~h} \mathrm{(4).} \mathrm{Owing} \mathrm{chiefly} \mathrm{to} \mathrm{the} \mathrm{difficulty} \mathrm{in}$ preparing homogeneous populations of these other cell types, their growth and functional characteristics have not been studied as extensively. However, lipocytes, Kupffer cells, and endothelial cells can be isolated satisfactorily from normal rat liver $(5,6)$, whereas the model of choice for BEC isolation remains that of the bile duct ligated rat (7).

With access to both normal and diseased human liver tissue through the clinical transplantation program in this unit, our recent work has concentrated on the growth regulation of human liver cells. These studies have led us to conclude that many of the factors that are active in stimulating rat hepatocyte growth also retain bioactivity on isolated human hepatocytes although some important species differences are evident $(8,9)$. We have also developed a method which yields highly pure preparations of BEC from normal and diseased human liver $(10,11)$. However, although BEC isolated from rat liver will proliferate in culture $(7)$, isolated human cells have proven difficult to maintain in vitro (10-13). Even in the presence of enriched media, human BEC, in keeping with other epithelial cell types including keratinocytes and cervical epithelium (14, 15), require feeder-layer fibroblasts for survival. Furthermore, human BEC demonstrate only limited growth and do not survive more than one passage $(10,11)$.

Hepatocyte growth factor (HGF) is a high molecular mass growth factor $(95 \mathrm{kD})$ and is the most potent mitogen yet found for hepatocytes in vitro $(8,16-19)$. Recently HGF has been shown to be identical to lung fibroblast growth factor (20), indicating that it is not liver specific. Indeed HGF acts as a mitogen for epithelial cells from a number of tissues (20-22) and a wide tissue distribution of the polypeptide has recently been reported (23). Additionally, scatter factor, which induces epithelial and endothelial cell migration (24), is also identical to HGF (25). However, despite its ubiquitous presence, HGF is thought by some investigators to be the primary mitogen that initiates the growth response in hepatocytes after partial hepatectomy or tissue injury $(16,26)$. In this report, we present data that indicate that human BEC proliferate in response to $\mathrm{HGF}$,

1. Abbreviations used in this paper: BEC, biliary epithelial cells; HGF, hepatocyte growth factor; PBC, primary biliary cirrhosis. 
which heretofore has been considered to be growth specific at least in the liver for hepatocytes $(17,18,26)$.

\section{Methods}

Hepatocyte growth factor. Recombinant human HGF was purified from Chinese hamster ovary cell transfectants as previously described (8).

Isolation and culture of human biliary epithelial cells. Normal liver was obtained from reduced grafts used for pediatric liver transplant recipients. Donor organs had been perfused with University of Wisconsin preservation fluid (27) and maintained at $4^{\circ} \mathrm{C}$ for $12-24 \mathrm{~h}$ before cell isolation. Primary biliary cirrhosis (PBC) liver (histological stage III and IV) was from hepatectomy specimens obtained through the orthotopic liver transplantation program.

Isolation of intrahepatic BEC from human liver is described in detail elsewhere $(10,11)$. Briefly, $\sim 30 \mathrm{~g}$ of liver was collagenase digested, followed by immunomagnetic purification of BEC using a monoclonal antibody, HEA125 (Progen Biotechnik, Heidelberg, FRG). This antibody recognizes an $M_{\mathrm{r}} 34,000 \mathrm{KD}$ cell surface glycoprotein expressed by epithelial cells from numerous tissues $(28)$ but absent from mesenchymal and mesothelial cells (28). In the liver, however, hepatocytes are negative and HEA 125 staining is confined to BEC $(10,11,28)$. Additionally, hepatic capsular mesothelial cells were also negative for HEA125 (not shown). Immunoisolated BEC were resuspended in BEC plating medium composed of 45\% Ham's F12 medium (Gibco Laboratories, Grand Island, NY), 45\% Dulbecco's modification of Eagle's medium (DME, Gibco Laboratories), $10 \%$ fetal bovine serum (FBS), insulin ( $5 \mu \mathrm{g} / \mathrm{ml})$, epidermal growth factor $(10 \mathrm{ng} / \mathrm{ml})$, cholera toxin $(10 \mathrm{ng} / \mathrm{ml})$, hydrocortisone $(0.4 \mu \mathrm{g} / \mathrm{ml})$, triiodothyronine ( $2 \mathrm{nM})$, streptomycin $(40 \mu \mathrm{g} / \mathrm{ml})$, and penicillin $(24 \mu \mathrm{g} / \mathrm{ml})$.

The cells were plated in $25-\mathrm{cm}^{3}$ tissue culture flasks ( stock cultures) or 2-cm ${ }^{3}$ wells (24-well plates for growth assays). After allowing 24-48 $\mathrm{h}$ for attachment, plating medium was replaced with growth medium which contained reduced serum (5\% FBS) and hHGF. BEC stocks were cultured in medium supplemented with $10 \mathrm{ng} / \mathrm{ml}$ hHGF which was renewed every other day. At confluence, cells were passaged using trypsin and replated at $25 \%$ density. For cryopreservation, cells grown in the presence of $10 \mathrm{ng} / \mathrm{ml}$ were suspended in freezing medium (50\% FBS, $10 \%$ dimethyl sulfoxide, $40 \%$ DME). They were cooled in the liquid $\mathrm{N}_{2}$ vapor phase overnight and stored at $-140^{\circ} \mathrm{C}$ for up to $30 \mathrm{wk}$.

Growth assays and characterization of cells. BEC in 24-well plates were cultured with a range of concentrations of hHGF $0.01-200 \mathrm{ng} / \mathrm{ml}$ (minimum of triplicate wells) for $7 \mathrm{~d}$. Culture medium was changed every other day, $1.5 \mu \mathrm{Ci} / \mathrm{ml}$ of $\left[{ }^{3} \mathrm{H}\right]$ thymidine (Amersham International, Amersham, UK; TRK328) was added for the final $5 \mathrm{~h}$ and the cells washed twice in PBS. After fixation in $70 \%$ ethanol and further washes (twice with PBS), cells were immunostained using a battery of monoclonal antibodies. BEC-specific markers were HEA125 (1:10) and CK-19 (Dako Ltd., High Wycombe, UK; 1:100). Antibodies to vimentin, factor VIII-related antigen, and desmin were used as controls (all Dako Ltd.; 1:100 dilution). Sites of primary antibody binding were visualized by using a three-stage immunoperoxidase method (Elite stain, Vector Labs, Inc., Burlingame, CA). After immunostaining the cells were washed with distilled water and air-dried, and $\left[{ }^{3} \mathrm{H}\right]-$ thymidine incorporation was visualized by autoradiography using Ilford $\mathrm{K}_{2}$ photographic emulsion (Ilford Ltd., Cheshire, UK) (29).

Quantitation and statistics. For determination of the S-phase labeling index, the plates were examined using an inverted microscope (Olympus Corp., Lake Success, NY) fitted with an eyepiece graticule and a $\times 20$ objective. Three separate fields in each of a minimum of triplicate wells were scored for labeled and unlabeled nuclei ( minimum of nine fields at each concentration of hHGF, representing between 300 and 500 cells). The method was validated by comparing the scores with those of two other independent scorers. Friedman analysis showed no difference in the distribution of the three sets of scores $(P=0.14)$ and Wilcoxon signed rank analysis of pairs showed no significant dif- ference between the scores $(P>0.7)$. The data presented represents the mean score \pm standard deviation of the three independent scorers. Responses to hHGF were analyzed using Wilcoxon signed rank test; $P$ values $<0.05$ were considered significant.

\section{Results}

BEC cultured in the absence of hHGF survived in culture for 7-10 d and demonstrated only limited proliferation. Beyond that time, the cells gradually deteriorated, assuming a more flattened nonepithelial-like appearance, and subsequently detached from the substratum. By contrast, when cultured in the continual presence of $10 \mathrm{ng} / \mathrm{ml}$ hHGF, BEC could be maintained for up to 3 mo through at least five passages. Whereas previous attempts to cryopreserve BEC had been unsuccessful, the viability of subcultured hHGF treated cells after freezing and thawing was $60-80 \%$.

Primary BEC isolates demonstrated dose-dependent proliferation in response to hHGF with a clear increase in cell number, resulting in near-confluent monolayers within 7-10 d (Fig. 1). Maximal growth of BEC was seen at $10-100 \mathrm{ng} / \mathrm{ml} \mathrm{hHGF}$, with a reduction at higher doses (Fig. 1). After autoradiography, the S-phase labeling index of BEC cultures rose markedly (Fig. 2). At lower doses, labeled cells were located predominantly near the edges of colonies (Fig. $2 b$ ). However at high doses, cells in the center of confluent monolayers also labeled strongly (Fig. 2, $c$ and $d$ ).

The S-phase $\mathrm{LI}$ rose to a maximum of $\sim 40 \%$ between 10 and $100 \mathrm{ng} / \mathrm{ml} \mathrm{hHGF} \mathrm{(Fig.} \mathrm{3).} \mathrm{However,} \mathrm{increased} \mathrm{prolifera-}$ tion could be detected with as little as $0.01-0.1 \mathrm{ng} / \mathrm{ml} \mathrm{hHGF}$ (Fig. 3). Half-maximal stimulation occurred at $\sim 1 \mathrm{ng} / \mathrm{ml}$. In keeping with our previous observations that cells isolated from both normal and PBC livers retained similar morphological and functional characteristics $(10,11)$, the growth responses to hHGF of both populations were indistinguishable (Figs. 3 and 4). At $10 \mathrm{ng} / \mathrm{ml} \mathrm{hHGF}$ the degree of stimulation of BEC from eight subjects (three normals and five PBCs) was similar (Fig. 4).

To determine the phenotype of cells responding to hHGF, cultures were immunostained with antibodies against intermediate filaments and cell surface markers. Cells that proliferated in response to hHGF stained positively for CK-19 and

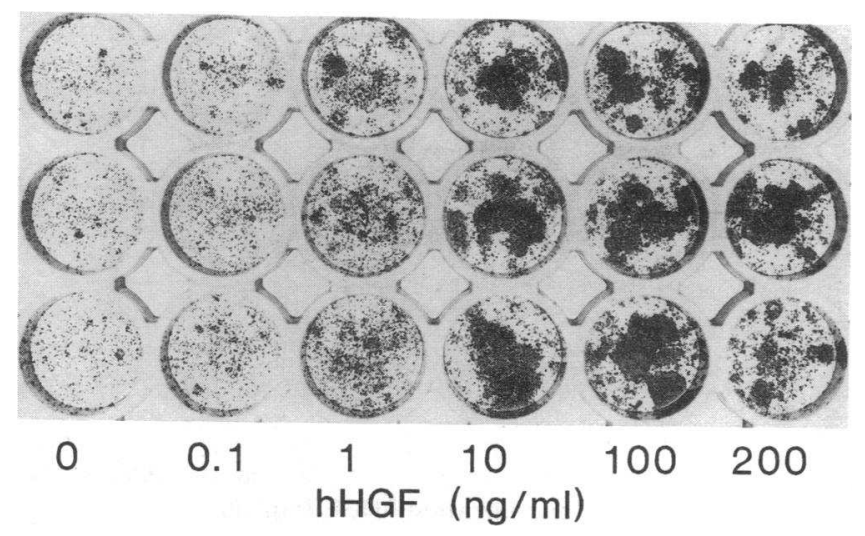

Figure 1. Assay plate showing the dose-dependent response of BEC from normal liver cultured continuously with a range of concentrations of hHGF (triplicates) for $7 \mathrm{~d}$. Cells were immunostained with anti-CK-19 antibody. 

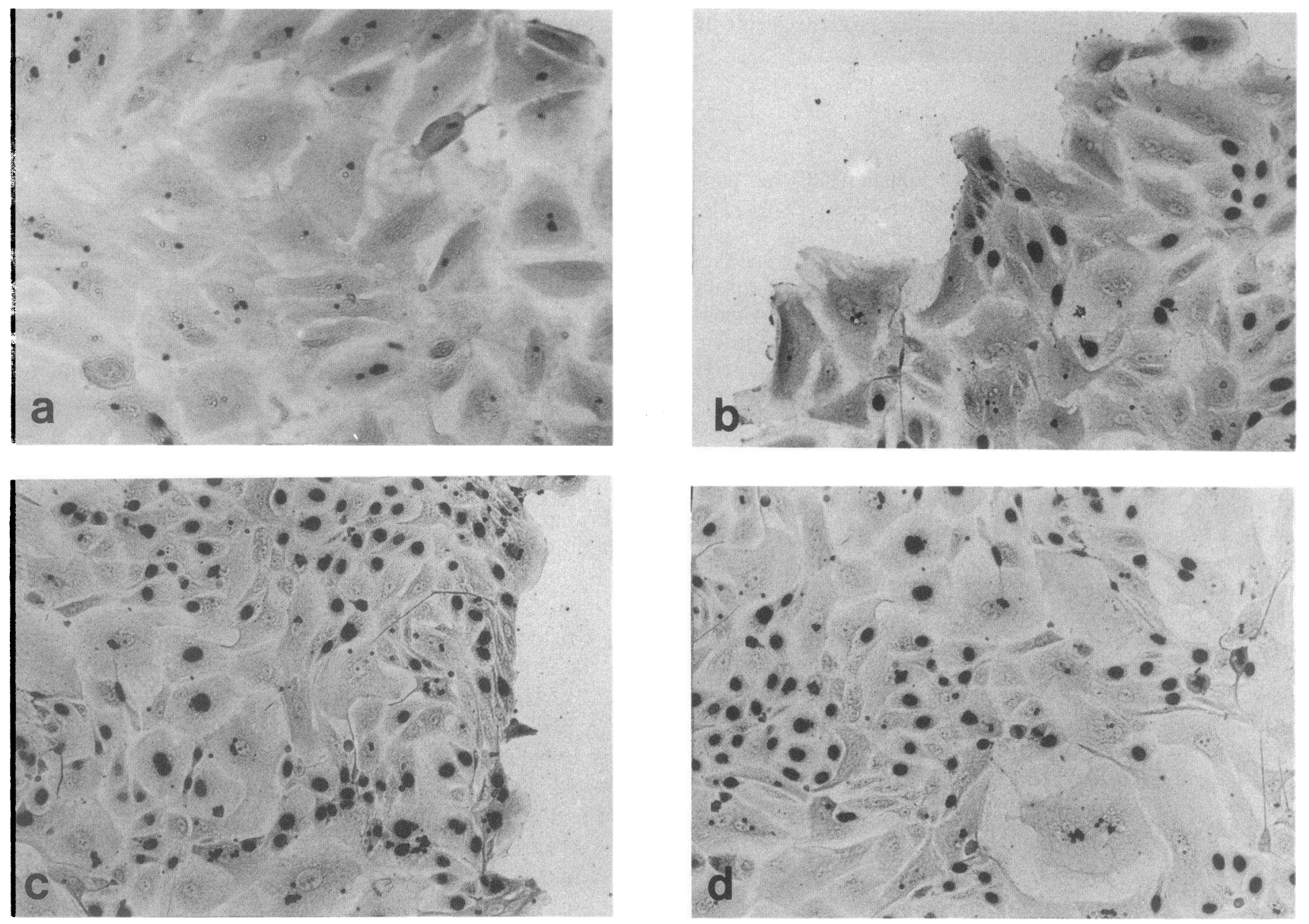

Figure 2. 7-d culture of BEC isolated from a normal liver cultured in standard epithelial cell medium: $(a)$ without hHGF, $(b)$ with $0.1 \mathrm{ng} / \mathrm{ml},(c)$ $10 \mathrm{ng} / \mathrm{ml}$, and $(d) 100 \mathrm{ng} / \mathrm{ml} \mathrm{hHGF}$. At low doses of hHGF, cells that had incorporated $\left[{ }^{3} \mathrm{H}\right.$ ] thymidine were located at or near the periphery of BEC colonies $(b)$ whereas at high concentrations cells at the center of colonies were labeled also $(c$ and $d)$.

HEA125 (Fig. 5, $a$ and $b$ ), both specific in the liver for biliary cells. HEA125 staining was clearly membranous (Fig. $5 a$ ) while CK-19 was cytoplasmic (Fig. $5 b$ ), consistent with their expected cellular localisation. HEA125 and CK-19 expression could be detected in BEC which had been grown, and passaged at least twice, in the presence of $10 \mathrm{ng} / \mathrm{ml} \mathrm{hHGF}$ for $3 \mathrm{wk}$ (results not shown).

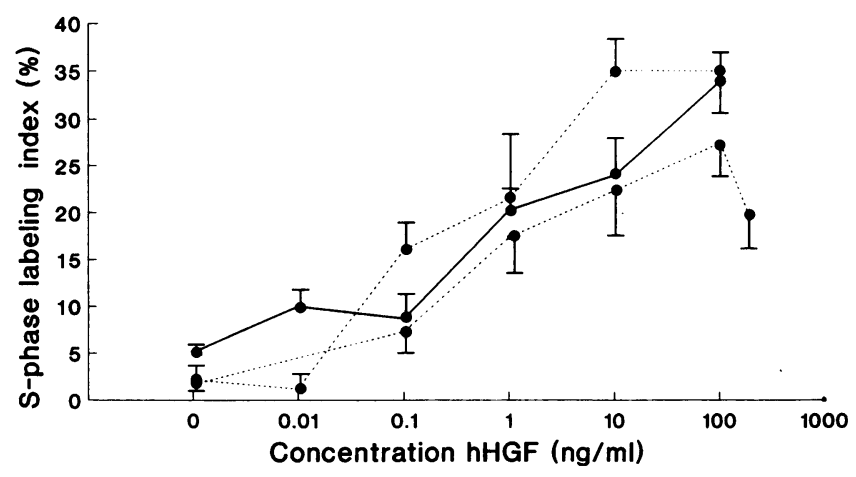

Figure 3. The dose response of BEC from two normal subjects (dashed lines) and one PBC patient (solid line). The values given represent the mean labeling index of at least nine fields of view \pm the standard deviation of three independent scorers.
The S-phase labeled cells were negative for vimentin (Fig. 5 c), an intermediate filament normally localized exclusively to cells of mesenchymal origin. However, occasional single vimentin-positive cells were observed ( $\sim 2 \%$ of total cell number), often surrounded by $\left[{ }^{3} \mathrm{H}\right]$ thymidine labeled cells (Fig. 5 c). These vimentin-positive cells were nonproliferative because they consistently failed to incorporate $\left[{ }^{3} \mathrm{H}\right]$ thymidine. Finally, cultures were found to be negative for desmin and factor VIIIrelated antigen expression (not shown). The pattern of immunostaining was similar in hHGF cultured BEC from both normal and PBC liver.

\section{Discussion}

The development of a reliable technique to isolate homogeneous populations of human intrahepatic biliary epithelial cells $(10,11)$ has led to novel experimental studies into the etiology of diseases of the biliary epithelium $(30,31)$. However, these studies have been limited by the relatively small yield of cells attainable by means of the immunomagnetic separation technique $(10,11)$ and by the dependence on growth-arrested fibroblast feeder layers. In this report, we describe an important advance, namely that proliferation of human BEC in response to human HGF leads to greatly increased numbers of cells with 


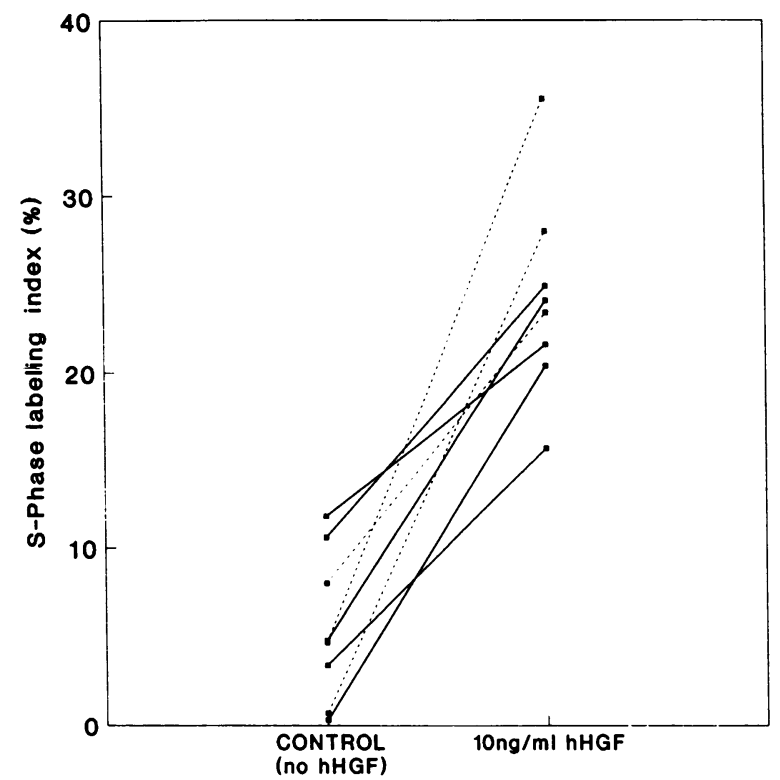

Figure 4. The response of BEC from three normal subjects (dashed lines) and five PBC patients (solid lines) to $10 \mathrm{ng} / \mathrm{ml}$ hHGF. The mean labeling index of hHGF-treated cells was higher than that of untreated cells $(P<0.01$ Wilcoxon signed rank test $)$.

which to conduct such studies. Human HGF-treated BEC no longer require fibroblast feeder-layer support $(10,11)$, can be serially passaged, and can be successfully cryopreserved and stored for future studies.

Recent developments indicate that hHGF is not solely a mitogen for hepatocytes, but stimulates the growth of epithelial cells from kidney, breast, lung, and skin (20-22). In addition, both HGF mRNA and protein have been detected in a wide array of cells and tissues $(18,23)$. Notably, although expressed and released by fibroblasts, it appears to have little bioactivity on cells of mesenchymal origin (20-22). Endothelial cells, which proliferate and / or migrate in response to $\operatorname{HGF}(20,24)$, are an exception. HGF seems therefore to belong to a distinct family of growth factors, namely those which act predominantly on epithelial cells. The recently characterized keratinocyte growth factor (32), a member of the fibroblast growth factor superfamily (33), also fits into this category. Therefore the observation that hHGF is mitogenic for isolated BEC as well as hepatocytes from the liver is consistent with its actions on cells from other tissues.

The evidence that indicates that the population of cells responding to hHGF are truly biliary epithelial in origin and not from some minor contaminant cell type present in the initial cell isolate is convincing. First, as discussed above, with the exception of endothelial cells $(20,24)$, the reported biological activity of hHGF in vitro has to date been confined to cells of epithelial origin (20-22). Secondly, cells grown in the presence of hHGF for up to $3 \mathrm{wk}$ and two passages retain expression of CK-19 the BEC-specific intermediate filament (34) and the cell surface antigen expressed exclusively by BEC in the liver which is recognized by the antibody HEA $125(10,28)$. Lastly, hHGF-treated cultures were negative when immunostained with antibodies against desmin and factor VIII-related antigen, markers for lipocytes and endothelial cells, respectively. Thus the possibility that the population of cells responding to hHGF represents a minor nonepithelial cell contaminant seems unlikely.

Although occasional vimentin-positive cells were observed (Fig. $4 c$ ), it was notable that those cells consistently failed to label with thymidine. Although their precise origin remains in question and it is possible that they represent a minor contaminant from the preparative procedure, this is considered unlikely. Recent reports indicate that vimentin may not be confined to cells of mesenchymal origin, but can be found in epithelial cells from several different tissues (35-38). Moreover, Milani et al. (39) have shown vimentin expression in cells of newly formed rat bile duct epithelial cells after bile duct ligation in the rat. Interestingly, as shown here, they found that a very low percentage of vimentin-positive cells were actively proliferating. Thus we conclude that the small population of
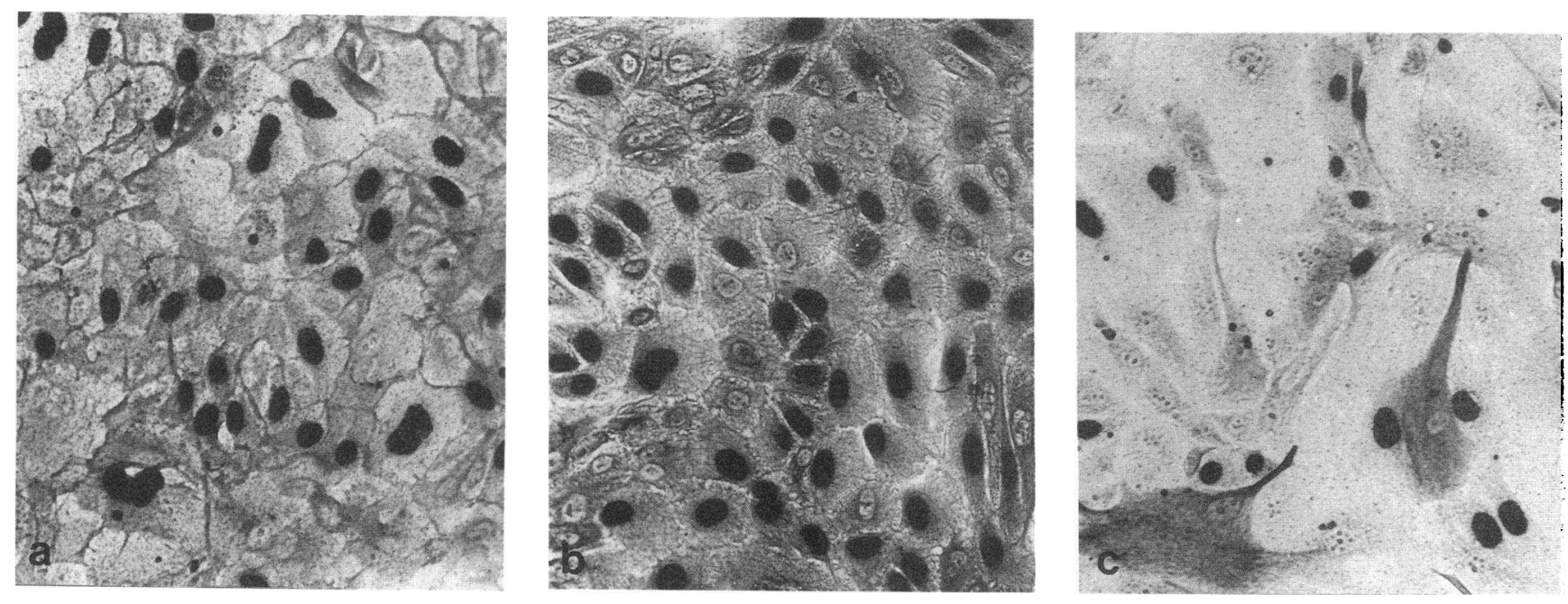

Figure 5. Characterization of proliferating cells by immunocytochemistry using the BEC markers $(a)$ HEA125 and $(b)$ CK-19 and $(c)$ a marker not normally expressed by BEC, vimentin. Cell isolates were from ( $a$ and $b$ ) normal liver and $(c)$ PBC liver. $(a)$ The proliferating cells showed a staining pattern with HEA125 which was associated predominantly with the plasma membrane. $(b)$ Strong staining of the cytoplasm resulted when anti-CK-19 antibodies were used. $(c)$ Proliferating cells were negative for anti-vimentin antibody with occasional nonproliferating cells staining positively. 
vimentin-positive cells identified in the present study may indeed be BEC-derived.

The fact that human BEC respond to hHGF in vitro has important consequences. HGF is strongly implicated in the initiation of liver regeneration in that its expression increases after hepatectomy considerably earlier than the other mitogenic agents. Circulating levels of HGF rise within $1-2 \mathrm{~h}$ after hepatectomy in the rat (26). This HGF is thought to be from extrahepatic sources inasmuch as intrahepatic HGF expression only rises after $\sim 3-6 \mathrm{~h}(40,41)$. In addition, HGF is the most potent hepatocyte mitogen known $(8,16-19)$. In animals (and probably in human) hepatocytes lead the regenerative response whether induced by toxins, viruses, or surgery with the other cell types including biliary epithelial cells following some $24 \mathrm{~h}$ later $(3,4)$. Thus, if as is suggested by currently available evidence, hHGF is the primary mitogen in initiating liver regeneration, then it is clearly necessary to invoke some mechanism whereby the response to endocrine (or paracrine) hHGF is restricted to the liver and, furthermore, to a given cell type and/or location within the tissue during the regenerative response.

In this regard, the recent demonstration of HGF receptor expression in both biliary epithelial cells and hepatocytes on histological sections of normal human liver (42) is of interest. Clearly this supports the concept that HGF is an important mitogen for BEC in vivo as well as in culture. However, it also indicates that target cell specificity does not simply rest in the ability of a given cell type to express the receptor. Indeed the HGF receptor has been localized in many different cells and tissues (42). The mechanism whereby the cell-specific targeting of the biological activity of HGF comes about remains unknown.

\section{Acknowledgments}

We are grateful to Dr. S. Hubscher, Department of Pathology, for assessment of histological sections, to Ms. L. Hart for technical assistance, and to the surgical teams led by Mr. P. McMaster, J. Buckels, and D. Mayer for help with collection of liver specimens.

This work was supported by grants from the Wellcome Trust and the Childrens Liver Disease Foundation.

\section{References}

1. McGowan, J. A. 1986. Hepatocyte proliferation in culture. In Research in Isolated and Cultured Hepatocytes. A. Guillouzo, and C. Guguen-Guillouzo, editors. John Libby/INSERM, London. 13-24.

2. Fausto, N., and J. E. Mead. 1989. Regulation of liver growth: protooncogenes and transforming growth factors. Lab. Invest. 60:4-13.

3. Bucher, N. L. R., and A. J. Strain. 1992. Regulatory mechanisms in hepatic regeneratior. In Wright's Liver and Biliary Disease. G. H. Millward-Sadler, R. Wright, and M. J. P. Arthur, editors. W. B. Saunders Co., Ltd., London. 258-274.

4. Bucher, N. L. R. 1982. Thirty years of liver regeneration: a distillate. Cold Spring Harbor Conf. Cell Proliferation. 15-24.

5. Knook, D. L., and E. C. Sleyster. 1976. Separation of kupffer and endothelial cells of the rat liver by centrifugal elutriation. Exp. Cell. Res. 99:444-449.

6. Friedman, S. L., and F. J. Roll. 1987. Isolation and culture of hepatic lipocytes, Kupffer cells and sinusoidal endothelial cells by density gradient centrifugation with Stractan. Anal. Biochem. 161:1233-1247.

7. Sirica, A. E., G. A. Mathis, N. Sano, and L. E. Elmore. 1990. Isolation, culture and transplantation of intrahepatic biliary epithelial cells and oval cells. Pathobiology. 58:44-64.

8. Strain, A. J., T. Ismail, H. Tsubouchi, N. Arakaki, T. Hishida, N. Kitamura, Y. Daikuhara, and P. McMaster. 1991. Native and recombinant human hepatocyte growth factors are highly potent promoters of DNA synthesis in both human and rat hepatocytes. J. Clin. Invest. 87:1853-1857.
9. Ismail, T., J. Howl, M. Wheatley, P. McMaster, J. Neuberger, and A. J. Strain. 1991. Growth of normal human hepatocytes in primary culture: Effect of hormones and growth factors on DNA synthesis. Hepatology. 14:1076-1082.

10. Joplin, R., A. J. Strain, and J. M. Neuberger. 1989. Immunoisolation and culture of biliary epithelial cells from normal human liver. In Vitro Cell Dev. Biol. 25:1189-1192.

11. Joplin, R., A. J. Strain, and J. M. Neuberger. 1990. Biliary epithelial cells from the liver of patients with primary biliary cirrhosis: isolation, characterization, and short-term culture. J. Pathol. 162:255-260.

12. Yoshitomi, S., K. Miyazaki, and F. Nakayama. 1987. Demonstration and maintenance of mucus secretion in cultured human gallbladder epithelial cells. In Vitro Cell Dev. Biol. 23:559-566.

13. Saidman, S. L., R. J. Duquesnoy, A. Zeevi, J. J. Fung, T. E. Starzl, and A. J. Demetris. 1991. Recognition of major histocompatibility complex antigens on cultured human biliary epithelial cells by alloreactive lymphocytes. Hepatology. 13:239-246.

14. Rheinwald, J. G., and H. Green. 1975. Serial cultivation of strains of human epidermal keratinocytes: the formation of keratinizing colonies from single cells. Cell. 6:331-344.

15. Stanley, M. A., and E. K. Parkinson. 1979. Growth requirements of human cervical epithelial cells in culture. Int. J. Cancer. 24:407-414.

16. Nakamura, T., K. Nawa, and A. Ichihara. 1984. Partial purification and characterization of hepatocyte growth factor from serum of hepatectomized rats. Biochem. Biophys. Res. Commun. 122:1450-1459.

17. Gohda, E., H. Tsubouchi, H. Nakayama, S. Hirono, O. Sakiyama, K. Takahashi, H. Miyazaki, S. Hashimoto, and Y. Daikuhara. 1988. Purification and partial characterization of hepatocyte growth factor from plasma of a patient with fulminant hepatic failure. J. Clin. Invest. 81:414-419.

18. Tashiro, K., M. Hagiya, T. Nishizawa, T. Seki, M. Shimonishi, S. Shimizu, and T. Nakamura. 1990. Deduced primary structure of rat hepatocyte growth factor and expression of the mRNA in rat tissues. Proc. Natl. Acad. Sci. USA. 87:3200-3204.

19. Zarnegar, R., and G. K. Michalopoulos. 1989. Purification and biological characterization of human hepatopoeitin A, a polypeptide growth factor for hepatocytes. Cancer Res. 49:3314-3320.

20. Rubin, J. S., A. M. L. Chan, D. P. Bottaro, W. H. Burgess, W. G. Taylor, A. C. Cech, D. W. Hirschfield, J. Wong, T. Miki, P. W. Finch, et al. 1991. A broad-spectrum human lung fibroblast derived mitogen is a variant of hepatocyte growth factor. Proc. Natl. Acad. Sci. USA. 88:415-419.

21. Kan, M., G. Zhang, R. Zarnegar, G. Michalopoulos, Y. Myoken, W. L. McKeehan, and J. I. Stevens. 1991. Hepatocyte growth factor/hepatopoietin A stimulates the growth of rat kidney proximal tubule epithelial cells (RPTE), rat nonparenchymal liver cells, human melanoma cells, mouse keratinocytes and stimulates anchorage-independent growth of SV-40 transformed RPTE. Biochem. Biophys. Res. Commun. 174:331-337.

22. Igawa, T., S. Danda, H. Kanetake, Y. Saitoh, A. Ichihara, Y. Tomita, and T. Nakamura. 1991. Hepatocyte growth factor is a potent mitogen for cultured rabbit renal tubular epithelial cells. Biochem. Biophys. Res. Commun. 174:831838.

23. Wolf, H. K., R. Zarnbegar, G. K. Michalopoulos. 1991. Localization of hepatocyte growth factor in human and rat tissues: an immuno-histochemical study. Hepatology. 14:488-494.

24. Rosen, E. M., S. Jaken, W. Carley, P. Luckett, E. Setter, M. Bhargava, and I. D. Goldberg. 1991. Regulation of motility in bovine brain endothelial cells. $J$. Cell. Physiol. 146:325-355.

25. Weidner, M., N. Arakaki, G. Hartmann, J. Vanderkerchove, S. Weingart, H. Rieder, C. Fonatsch, H. Tsubouchi, T. Hishida, Y. Daikuhara, et al. 1991. Evidence for the identity of human scatter and human hepatocyte growth factor. Proc. Natl. Acad. Sci. USA. 88:7001-7005.

26. Lindroos, P. M., R. Zarnegar, and G. K. Michalopoulos. 1990. Hepatocyte growth factor (hepatopoietin A) rapidly increases in plasma before DNA synthesis and liver regeneration stimulated by partial hepatectomy and carbon tetrachloride administration. Hepatology. 13:743-750.

27. Belzer, F. O., and J. H. Southard. 1988. Principles of solid-organ preservation by cold storage. Transplantation (Baltimore). 45:673-676.

28. Momberg, F., G. Moldenhauer, and G. H. Hammerling. 1987. Immunohistochemical study of the surface expression of a $M_{\mathrm{r}} 34,000$ human epitheliumspecific glycoprotein in normal and malignant tissues. Cancer Res. 47:28832891.

29. Strain, A. J., J. A. McGowan, N. L. R. Bucher. 1982. Stimulation of DNA synthesis in primary cultures of adult rat hepatocytes by rat platelet-associated substances. In Vitro (Rockville). 18:108-116.

30. Joplin, R., J. G. Lindsay, G. D. Johnson, A. J. Strain, and J. Neuberger. 1992. Membrane dihydrolipoamide acetyltransferase (E2) on human biliary epithelial cells in primary biliary cirrhosis. Lancet. 339:93-94.

31. Ayres, R. C. S., J. Shaw, C. O. Mills, R. Coleman, and J. M. Neuberger. 1991. A chromium release cytotoxicity assay for use with biliary epithelial cells. $J$. Immunol. Methods 141:117-122.

32. Rubin, J. S., H. Osada, P. W. Finch, W. G. Taylor, S. Rudikoff, and S. A. 
Aaronson. 1989. Purification and characterization of a newly identified growth factor specific for epithelial cells. Proc. Natl. Acad. Sci. USA. 86:802-806.

33. Burgess, W. H., and T. Maciag. 1989. The heparin-binding growth factor family of proteins. Annu. Rev. Biochem. 58:575-606.

34. van Eyken, P., R. Sciot, B. van Damme, V. J. de Wolf-Peeters, and V. Desmet. 1987. Keratin immunohistochemistry in normal human liver. Cytokeratin pattern of hepatocytes, bile ducts and acinar gradient. Virchows. Arch. 412:63-72.

35. Ben-Ze'Ev, A. 1984. Differential control of cytokeratins and vimentin synthesis by cell-cell contact and cell spreading in cultured epithelial cells. J. Cell Biol. 99:1424-1433.

36. van Eyken, P., R. Sciot, and V. Desmet. 1988. Intrahepatic bile duct development in the rat: a cytokeratin-immunohistochemical study. Lab. Invest. 59:52-59.

37. Kasper, M., and U. Karsten. 1988. Co-expression of cytokeratin and vimentin in Rathke's cysts of the human pituitary gland. Cell Tissue Res. 253:419424.
38. Grone, H.-J., K. Weber, E. Grone, U. Helmchen, and M. Osborn. 1987. Co-expression of keratin and vimentin in damaged and regenerating tubular epithelia of the kidney. Am. J. Pathol. 129:1-8.

39. Milani, S., H. Herbst, D. Schuppan, G. Niedobitek, K. Y. Kim, and H. Stein. 1989. Vimentin expression of newly formed rat bile duct epithelial cells in secondary biliary fibrosis. Virchows Archiv. A. Pathol. Anat. 415:237-242.

40. Kinoshita, T., K. Tashiro, and T. Nakamura. 1989. Marked increase of HGF mRNA in non-parenchymal liver cells of rats treated with hepatotoxins. Biochem. Biophys. Res. Commun. 165:1229-1234.

41. Zarnegar, R., M. C. DeFrances, D. P. Kost, P. Lindroos, and G. K. Michalopoulos. 1991. Expression of hepatocyte growth factor mRNA in regenerating rat liver after partial hepatectomy. Biochem. Biophys. Res. Commun. 177:559565.

42. Prat, M., R. P. Narsimhan, T. Crepaldi, P. G. Nicotra, P. G. Natali, and P. M. Comoglio. 1991. The receptor encoded by the human c-Met oncogene is expressed in hepatocytes, in epithelial cells and in solid tumours. Int. J. Cancer. 49:323-328. 